\title{
Air conditioning systems and nosocomial infections in Mosul hospitals
}

\author{
Karam A. Al-dabbagh, Manal F. Mohammed \\ Department of Pharmacology, College of Pharmacy, University of Mosul, Iraq
}

Received Accepted

T.. I. Y. . .

Y.9.Y.1.

ABSTRACT

Background: Nosocomial infections (NIs) have proven to be persistent and sometimes complicated problem. More than one third of all nosocomial infections possibly involve airborne transmission. The aim of this study is to estimate the types of bacteria that could be present in air-conditioning systems of some hospitals and their antibiotic sensitivity profile.

Materials and methods: Swab samples were taken from air-conditioning system filters and rendered for bacterial identification and evaluation of their antibiotic susceptibility.

Results: The results showed twenty isolates from three different hospitals. Ibn Sina showed 17 isolates ( 0 S. aureus; $\Gamma$ S. epidermidis; $₹$ S. saprophyticus; 1 E. coli; 1 Proteus mirabilis; ' Klebsiella pneumoniae and I Pseudomonas aeruginosa), Ibn AlAtheer hospital showed only $r$ isolates (' S.aureus, and I Streptococcus) and AlJumhori hospital showed only $r$ isolates (' S. aureus, and ' S. saprophyticus); most of this isolates are resistant to the antibiotics used in this study.

Conclusion: there are a risky bacteria located in air conditioners especially indoor conventional systems more than the hospital designed systems and still both represent a susceptible source for nosocomial infection.

Keywords: nosocomial, air-conditioning systems, airborne infection

الخلفية: أثبتت العديد من الدراسات بان الإصابة المكتسبة من المستشفى هي إصابة طويلة الأمد و قد تكون مشكلة معقدة. أكثر من ثلث الإصابات المكتسية من المستشفى هي إصابات مكتسبة من جو المستشفى (الهواء المحيط بالمريض) مدة. الهدف من هذه الدراسة هو لتقييم أنواع البكتيريا التي قد تكون موجودة في أنظمة تكييف الهو اء في المستشفيات

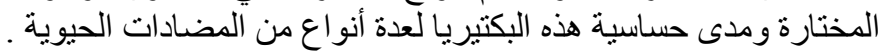

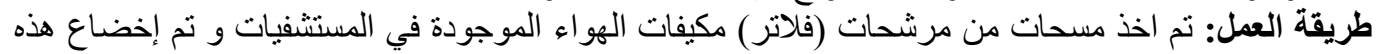

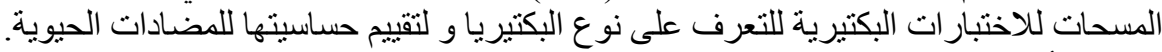

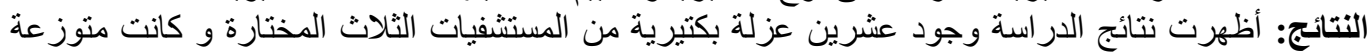

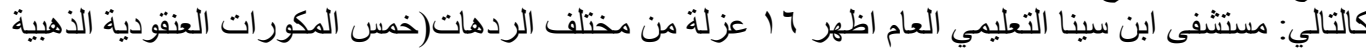
،ثلاث من المكور ات العنقودية الفضية ، أربع من العنقوديات الحمضيات ، عزلة الة واحدة من عصبيات أي كولاي

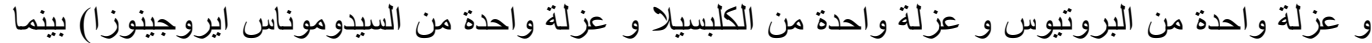

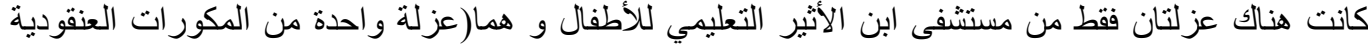

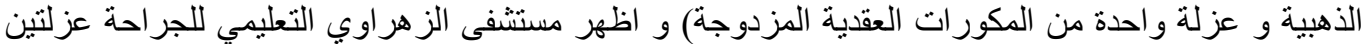

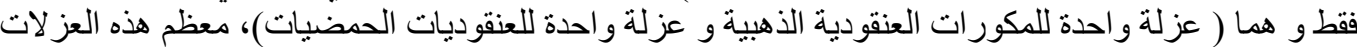

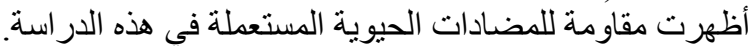

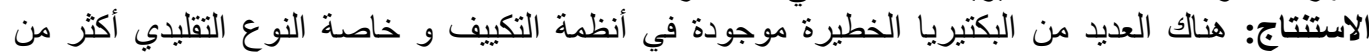

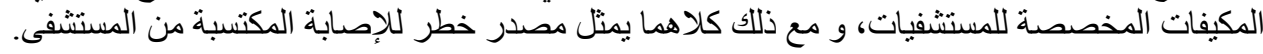


$\mathbf{N}$ osocomial infections (NIs) are those that acquired in a hospital sitting, the associated infections occur after $\leqslant \wedge$ hours of ICU admission or within $\leqslant \wedge$ hours after transfer from an ICU', and these infections are not present at admission ${ }^{r}$. Two million people become ill each year as a result of hospital acquired infections ${ }^{r}$, and contributed to the death of nearly $q, \cdots$ hospital patients per year ${ }^{r}$.

Ninety percent of the NIs caused by bacteria whereas mycobacterial, viral, fungal, or protozoal agents are less commonly involved. Klebsiella pneumoniae, Staphylococcus aureus, Escherichia coli, Proteus mirabilis, and Pseudomonas aeruginosa are among the most common causative agents of NIs ${ }^{\text {. }}$. Large use of broad spectrum antibiotics in hospital environment promoted emergence of a newer organisms such as acinetobacter baumanni, Sternotrophomonas maltophilia and Burkholdereria cepaci $\varepsilon$

If transmission by direct contact predominates as many experts suggest, then surface disinfection technologies should have a major impact in reducing infection rates. But with more than a third of all nosocomial infections possibly involving airborne transmission at some point, the combination of surface and air disinfection should produce optimum results ${ }^{\circ}$.

Airborne transmitted nosocomial infections is estimated between 1.$17 \%$ of total ICU nosocomial infections s, $^{\circ}$, the total number of airborne viable particles in this critical areas, seems to be a significant risk factor for the development of nosocomial infections in immune compromised patients ${ }^{r, ?}$.
Airborne transmission is the transfer of particles measures ${ }^{\circ} \mu \mathrm{m}$ or less in size into the air, either as airborne droplets or dust particles containing the infectious microorganisms that can be produced by coughing, sneezing, talking or procedures such as bronchoscopy or suction. These particles can remain in the air for several hours; and can be spread widely within a room or over longer distance ${ }^{\gamma}$. Special air handling and ventilation are needed to prevent airborne transmission ${ }^{\gamma}$. Each nosocomial infection adds $\left.0_{-}\right) \cdot$ days to the affected patient's time in the hospital, increasing morbidity and mortality of hospitalized patients especially the ones admitted in an intensive care units ${ }^{\lambda-1 r}$.

Many researchers determined that the reservoir of the deadly pathogen was the air conditioning systems and although many measures were taken to control the out breaks but it did never ended until the air conditionings system were sterilized and controlled iః.

This study aimed to find the type of pathogens that could be present in air conditioning systems in three hospitals in Mosul city, and to detect the antibiotic sensitivity profile of these pathogens.

\section{Materials and methods}

Swabs were taken from the inner filters of the air conditioning systems of three hospitals in Mosul city, represented as general hospital (Ibn Sina), pediatric hospital (Ibn Al-Atheer) and surgical hospital (Al-Jumhori). Swabs are commercially available type Citotest transport swab, totally $\backslash \wedge$ swabs were used. 
Samples were collected in autumn r... T. Two weeks after the maintenance period for the air conditioning systems i.e. annual washing and cleaning, and the swab samples were taken from surgery, burns, pediatric yards, respiratory care unit (RCU), cardiac care unit (CCU), central laboratories, ECHO imaging room and artificial kidney yards and from the central units on the hospital roof.

The samples were analyzed in microbiology laboratory in the College of Pharmacy, University of Mosul. Swabs were inoculated in blood and MacConkey agar then isolated colonies were subcultured in nutrient agar slants, then isolated for pure cultures. identification of the pure cultures was conducted by using morphological study by Gram stain, colony morphology on selective medias, and biochemical tests, which included Indole test, Voges-Proskauer test, citrate test, urease test, and sugar fermentation tests. The identified bacteria were rendered for antibiotics sensitivity test, five antibiotics were used: cefotaxime $r \cdot \mu \mathrm{g}$, rifampicin ${ }^{\circ}$ $\mu \mathrm{g}$, cefadroxil $r \cdot \mu \mathrm{g}$, tetracycline $r$. $\mu \mathrm{g}$ and ciprofloxacine ${ }^{\circ} \mu \mathrm{g}$ as standard disks for antibiotic sensitivity testing ${ }^{10}$ using the Bauer's standard disk diffusion method".

\section{Results}

The total isolates from the three hospitals revealed that there were twenty active isolates from different yards of these hospitals.

Ibn Sina hospital revealed the largest number of isolates, from many different yards and departments totally sixteen isolates; while Ibn Al-Atheer pediatric hospital and Al-Jumhori surgical hospital revealed two isolates each only.

Ibn Sina hospital revealed five isolates of Staphylococcus aureus, seven coagulase negative Staphylococcus (CNS), one Klebsiella pneumoniae, one Escherichia coli, one Proteus mirabilis and one Pseudomonas aeruginosa as shown: 
Table 1. Types of isolated bacteria and location in Ibn-Sina general hospital

\begin{tabular}{|c|c|c|c|}
\hline Culture results/ yards & Gram -ve bacilli & Gram +ve cocci & $\begin{array}{c}\text { No } \\
\text { growth/yard }\end{array}$ \\
\hline Bacteriology lab. No. (\%) & $\cdot(\cdot \%)$ & ( ( $.10 \%)$ & \\
\hline ECHO room No. $(\%)$ & $\cdot(\cdot \%)$ & Y(IY.0\%) & \\
\hline $\begin{array}{l}\text { Emergency pediatric room } 1 \\
\text { No. }(\%)\end{array}$ & $\cdot(\cdot \%)$ & T(IY..0\%) & \\
\hline $\begin{array}{l}\text { Emergency pediatric room }{ }^{r} \\
\text { No. }(\%)\end{array}$ & $\cdot(\cdot \%)$ & $r(1 \wedge . \vee \circ \%)$ & \\
\hline Artificial kidney No. (\%) & $\cdot(\cdot \%)$ & I( $(., 0 \%)$ & \\
\hline RCU ' No. (\%) & $\cdot(\cdot \%)$ & $\cdot(\cdot \%)$ & No growth \\
\hline RCU Y No. (\%) & Y(IY. $.0 \%)$ & $\cdot(\cdot \%)$ & \\
\hline Pediatric yard No. (\%) & $\cdot(\cdot \%)$ & $\cdot(\cdot \%)$ & No growth \\
\hline Operation room No. (\%) & $Y(1 Y .0 \%)$ & $r(\backslash \wedge . \vee \circ \%)$ & \\
\hline Total No. (\%) & $\varepsilon(Y \circ \%)$ & $T Y(V \circ \%)$ & \\
\hline
\end{tabular}

Ibn Al-Atheer pediatric hospital revealed one Staphylococcus aureus

and one diplococcus as shown in Table r.

Table $r$. Types of isolated bacteria and location in Ibn Al-Atheer pediatric hospital

\begin{tabular}{|l|c|c|c|}
\hline Culture results/ yards & Gram -ve bacilli & Gram +ve cocci & No growth/yard \\
\hline Suction Fan & $\cdot(\cdot \%)$ & $\cdot(\cdot \%)$ & No growth \\
\hline Central unit & $\cdot(\cdot \%)$ & $1(0 \cdot \%)$ & \\
\hline Central unit & $\cdot(\cdot \%)$ & $1(0 . \%)$ & \\
\hline Total No. (\%) & $\cdot(\cdot \%)$ & $r(1) \%)$ & \\
\hline
\end{tabular}

While Al-Jumhori surgical hospital revealed two isolates one Staphylococcus aureus and one
Staphylococcus saprophyticus (CNS) as shown in Table r. 
Table ${ }^{r}$. Types of isolated bacteria and location in Al-Jumhori hospital

\begin{tabular}{|c|c|c|c|}
\hline Culture results/ yards & $\begin{array}{l}\text { Gram -ve } \\
\text { bacilli }\end{array}$ & Gram +ve cocci & No growth/yard \\
\hline $\begin{array}{l}\text { Central unit female } \\
\text { surgery } 1^{\text {st }} \text { yard }\end{array}$ & $\cdots(\cdot \%)$ & $\cdots(\cdot \%)$ & No growth \\
\hline $\begin{array}{l}\text { Central unit female } \\
\text { surgery } r^{\text {nd }} \text { yard }\end{array}$ & $\cdots(\cdot \%)$ & $1(0 . \%)$ & \\
\hline $\begin{array}{l}\text { Central unit female renal } \\
\text { ICU }\end{array}$ & $\cdots(\cdot \%)$ & $1(0 . \%)$ & \\
\hline $\begin{array}{l}\text { Central unit male renal } \\
\text { ICU }\end{array}$ & $\cdot \cdot(\cdot \%)$ & $\cdots(\cdot \%)$ & No growth \\
\hline $\begin{array}{l}\text { Female renal surgery } \\
\text { yard }\end{array}$ & $\cdots(\cdot \%)$ & $\cdots(\cdot \%)$ & No growth \\
\hline Male burn yard & $\cdots(\cdot \%)$ & $\cdots(\cdot \%)$ & No growth \\
\hline Female burn yard & $\cdots(\cdot \%)$ & $\cdots(\cdot \%)$ & No growth \\
\hline Total No. (\%) & $\cdot(\cdot \%)$ & $r(1 \cdots \%)$ & \\
\hline
\end{tabular}

The type of isolated bacteria and there percentage is listed in table $\varepsilon,{ }^{\circ}$ and 7 :

Table $\varepsilon$. The type and percentage of bacteria isolated in Ibn-Sina hospital

\begin{tabular}{|c|c|c|}
\hline Bacteria isolated & No. of isolates & Percentage $\%$ \\
\hline S. aureus & 0 & T. Y.\%\% \\
\hline $\begin{array}{l}\text { S. epidermidis and } S \text {. } \\
\text { saprophyticus Coagulase } \\
\text { negative staphylococcus } \\
(\mathrm{CNS})\end{array}$ & v & $\varepsilon r . \vee 0 \%$ \\
\hline E. coli & 1 & $7.50 \%$ \\
\hline K. pneumoniae & 1 & $7.50 \%$ \\
\hline P. mirabilis & 1 & $7.10 \%$ \\
\hline Ps. aeroginosa & 1 & $7.50 \%$ \\
\hline Total & 17 & $1 \ldots \%$ \\
\hline
\end{tabular}


Table ${ }^{\bullet}$. The type and percentage of bacteria isolated in Ibn-AlAtheer hospital

\begin{tabular}{|l|c|c|}
\hline Bacteria isolated & No. of isolates & Percentage \% \\
\hline S.aureus & 1 & $0 . \%$ \\
\hline $\begin{array}{l}\text { S. epidermidis and S. } \\
\text { saprophyticus Coagulase } \\
\text { negative staphylococcus } \\
\text { (CNS) }\end{array}$ & 1 & $0 . \%$ \\
\hline Total & r & $1 \cdots \%$ \\
\hline
\end{tabular}

Table ${ }^{\top}$. The type and percentage of bacteria isolated in Al-Jumhori hospital

\begin{tabular}{|l|c|c|}
\hline Bacteria isolated & No. of isolates & Percentage \% \\
\hline S.aureus & 1 & $0 . \%$ \\
\hline $\begin{array}{l}\text { S. epidermidis and S. } \\
\text { saprophyticus Coagulase } \\
\text { negative staphylococcus } \\
\text { (CNS) }\end{array}$ & 1 & $0 . \%$ \\
\hline Total & $r$ & $1, \%$ \\
\hline
\end{tabular}

Antibiotic sensitivity profile for these isolates showed in table $\vee, \wedge$ and $\uparrow$ as follow: 
Table $\vee$. Ibn Sina general hospital isolates culture and sensitivity results as Sensitive / Total isolates (sensitive \%)

\begin{tabular}{|c|c|c|c|c|c|}
\hline \multirow[t]{2}{*}{ Bacteria } & \multicolumn{5}{|c|}{ Antibiotic } \\
\hline & $\begin{array}{l}\text { Cefotaxim } \\
\mathrm{e}\end{array}$ & $\begin{array}{l}\text { Rifampicin } \\
\mathrm{e}\end{array}$ & $\begin{array}{l}\text { Cefadroxi } \\
1\end{array}$ & $\begin{array}{l}\text { Tetracyclin } \\
\mathrm{e}\end{array}$ & $\begin{array}{l}\text { Ciprofloxacin } \\
\text { e }\end{array}$ \\
\hline S. aureus &.$/ 0(. \%)$ & $r / 0(\tau . \%)$ &.$/ 0(. \%)$ &.$/ 0(. \%)$ & $1 / 0(Y \cdot \%)$ \\
\hline $\begin{array}{l}\text { S. } \\
\text { epidermidis }\end{array}$ & $\cdot / \Gamma(. \%)$ & 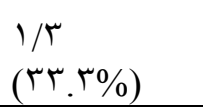 &.$/(. \%)$ & $\cdot / \Gamma(. \%)$ & I/r. \\
\hline $\begin{array}{l}\text { S. } \\
\text { saprophyticu } \\
\text { S }\end{array}$ & $\cdot / \varepsilon(\cdot \%)$ & $r / \varepsilon(0 . \%)$ &.$/ \varepsilon(. \%)$ & $\cdot / \varepsilon(\cdot \%)$ & $r / \varepsilon(0 . \%)$ \\
\hline E. coli &.$/(. \%)$ & $1 / 1(1 \ldots \%)$ &.$/ 1(. \%)$ &.$/ /(. \%)$ &.$/ 1(. \%)$ \\
\hline $\begin{array}{l}\text { K. } \\
\text { pneumoniae }\end{array}$ & $\cdot / /(\cdot \%)$ & $\cdot / /(. \%)$ &.$/ 1(. \%)$ &.$/(. \%)$ &.$/ 1(. \%)$ \\
\hline P. mirabilis &.$/(. \%)$ &.$/ 1(. \%)$ &.$/ 1(. \%)$ & $1 / 1(1 \cdots \%)$ &.$/ 1(. \%)$ \\
\hline $\begin{array}{l}\text { Ps. } \\
\text { aeroginosa }\end{array}$ & $\cdot / /(\cdot \%)$ &.$/ 1(. \%)$ & $\cdot / /(\cdot \%)$ & $\mathrm{N} / \mathrm{D}^{*}$ & $1 / 1(1 . \%)$ \\
\hline
\end{tabular}

*N/D: Not Determined

Table ^. Ibn Al-Atheer isolates culture and sensitivity results as Sensitive / Total isolates (sensitive \%)

\begin{tabular}{|l|l|l|l|l|l|}
\hline $\begin{array}{l}\text { Bacteria/antibiot } \\
\text { ic }\end{array}$ & $\begin{array}{l}\text { Cefotaxim } \\
\mathrm{e}\end{array}$ & $\begin{array}{l}\text { Rifampicin } \\
\mathrm{e}\end{array}$ & $\begin{array}{l}\text { Cefadrox } \\
\text { il }\end{array}$ & $\begin{array}{l}\text { Tetracyclin } \\
\mathrm{e}\end{array}$ & $\begin{array}{l}\text { Ciprofloxacin } \\
\mathrm{e}\end{array}$ \\
\hline S. aureus &.$/ 1(\cdot \%)$ &.$/ 1(\cdot \%)$ &.$/ 1(\cdot \%)$ &.$/ 1(\cdot \%)$ & $1 / 1(1, \% \%)$ \\
\hline Diplococcus &.$/ 1(\cdot \%)$ &.$/ 1(\cdot \%)$ &.$/ 1(. \%)$ &.$/ 1(. \%)$ & $1 / 1(1 . \% \%)$ \\
\hline
\end{tabular}


Table 9 . Al-Jumhori isolates culture and sensitivity results as Sensitive / Total isolates (sensitive \%)

\begin{tabular}{|c|c|c|c|c|c|}
\hline $\begin{array}{l}\text { Bacteria/antibiot } \\
\text { ic }\end{array}$ & $\begin{array}{l}\text { Cefotaxim } \\
\text { e }\end{array}$ & $\begin{array}{l}\text { Rifampicin } \\
\text { e }\end{array}$ & $\begin{array}{l}\text { Cefadrox } \\
\text { il }\end{array}$ & $\begin{array}{l}\text { Tetracyclin } \\
\text { e }\end{array}$ & $\begin{array}{l}\text { Ciprofloxacin } \\
\text { e }\end{array}$ \\
\hline S. aureus & $\cdot / /(. \%)$ & $\begin{array}{l}1 / 1 \\
(1 \cdots \%)\end{array}$ & $\cdot / /(. \%)$ &.$/(\cdot \%)$ & $\cdot / /(. \%)$ \\
\hline S. saprophyticus &.$/ 1(. \%)$ &.$/ /(. \%)$ &.$/ 1(. \%)$ &.$/(. \%)$ &.$/ /(. \%)$ \\
\hline
\end{tabular}

\section{Discussion}

The results showed many types of bacteria isolated from the three selected hospitals, all these bacteria are well known cause of worldwide nosocomial infections (especially pneumonia) ${ }^{\mathrm{iv}}$.

As shown in the results, interestingly there were many isolates from Ibn Sina hospital in comparison to so fewer isolates from Ibn Al-Atheer pediatric hospital and Al-Jumhori surgical hospital, and this variation could be explained on the basis of the type of air-conditioning systems that are used in these hospitals

Both Al-Jumhori and Ibn Al-Atheer hospitals use central units placed on the hospital roof with propelling system through specific filters and there are other separated suction systems that moves air from inside to outside the hospital. While in Ibn-Sina general hospital uses split unit airconditioners or window airconditioners in each room and it is well known the air conditioning system for such devices is via in-room air circulation (especially in split units system), i.e. there is no fresh filtered air pushed from outside to inside the hospital, but the in-hospital contaminated air is sucked by indoor split unit, recirculate it again into the hospital with a very high chance for the microbes to be settled in the dust filter and colonized there due to humidity and re spread again to cause infection to the next patients in that yard.

The distribution of bacteria through out the yards of the three hospitals may be related to the type of patients in each yard and/ or the type of treatment provided in that yard.

Staphylococcus species localized almost in all yards because it is considered as global first suspect in causing nosocomial infection even the commensal species like $S$. epidermidis or S. saprophyticus '^. Other types of bacteria like Klebsiella pneumonia and Pseudomonas aeruginosa located in RCU mostly due to the in-patients who carry this bacteria and contaminating the ventilators or aspiration systems, such result is in agreement with Akash Deep et $a l^{r, 19}$ and also established as a fact $^{r \cdot, r}$

On the other hand the E.coli and proteus mirabilis which are members of Enterobacteriaceae are considered as major causative bacteria for NIs in abdominal operation rooms ${ }^{14, Y 1}$. This is also documented in this study, whereas these bacteria were isolated from the air-conditioning system of the operation room from the general hospital which use the in-door split unit system. 
Many reports emphasized the importance of airborne nosocomial infections as one of the major sources of total nosocomial infection ${ }^{\gamma}$, and so fine dust or droplets generated by cough or speaking can cause spreading of bacteria which can remain viable in air for several hours until it could find a suitable host ${ }^{\mathrm{r}} \mathrm{r}^{\mathrm{r}}$, which is usually human (patient or working personnel) or suitable media to grow like air conditioners filter.

The culture and sensitivity test showed that almost all the isolated bacteria are highly resistant to most of the antibiotics used in this study, especially those which are highly prescribed in hospital (like cefotaxime), and there was one risky isolate (S.aureus) from artificial kidney yard showed no inhibition zone for all antibiotics used in this study.

E.coli, Klebsiella pneumoniae and pseudomonas aeruginosa resistance pattern is comparable to the pattern of Akash Deep et al $^{r}$, and so as the pattern of $S$. aureus which showed high resistance to almost all antibiotics used in this study, where $r$ isolates out of $V$ were totally resistant to all antibiotics in this study.

In conclusion hospital air conditioning systems can carry and spread risky types of bacteria that could cause higher morbidity and mortality to many patients.

\section{References}

1- Constantin M, Donisi PM, turrin MG. Hospital acquired infection surveillance and control in intensive care services. Results of an incidence study. Eur J epidemiol

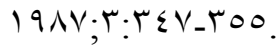

r- Akash Deep, Ghildiyal R, Kandian $\mathrm{S}$, et.al. Clinical and Microbiological profile of nosocomial infection in the pediatric intensive care unit(PICU). Indian Pediatrics

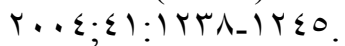

r- Haley RW, Culver DH, White JW, et al. The nationwide nosocomial infection rate: a new need for vital statistics. Am J Epidemiol 1910; IY): 109-7V.

¿ - Jain A, Singh K. Recent advances in the management of nosocomial infections. JK SCIENCE journal of medical education and researches. r..v; $;(1): r-\Lambda$.

๑. CDC. National Nosocomial Infections Surveillance (NNIS) System report, data summary from October 1917 through April 1997,

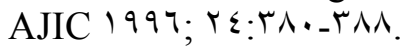

7- Durmaz G, Kiremitçi A, Akgün Y, et al. The relationship between airborne colonization and nosocomial infection in the intensive care unit. Mikrobiyol Bul r...0; rq( $\varepsilon):\left\{70_{-} V\right.$.

$\checkmark$ - Tietjen L, Bossemeyer D, McIntosh $\mathrm{N}$. Infection prevention a guidelines for healthcare facilities with limited resources. JHPIEGO. Corporation $r \cdot r \cdot r ; r: r$.

^. Daschner F. Nosocomial infections in intensive care units. Intensive

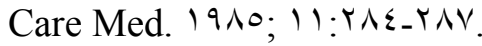

9. Correia M, Simao C, Lito LM, et al. Nosocomial infections in a Pediatric Intensive Care Unit. Acta Med Port. 199v;1,: : $7 r_{-} \leqslant 71$.

1.- Donowitz LG. High risk of nosocomial infection in the pediatric critical care patient. Crit

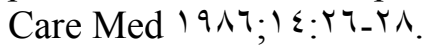

1)- Milliken J, Tait GA, Ford Jones $\mathrm{JL}$, et al. Nosocomial infection in a Pediatric Intensive Care Unit. Crit Care Med 1991;1 $1:$ r rr-Yrr.

$1 Y$ - Center for disease control: NNIS site Definitions Manual, Atlanta. GA. CDC. 19v०.

1T- Legras A, Robert R. Nosocomial infection: prospective survey of 


$$
\begin{aligned}
& \text { incidence in } 0 \text { French ICUs. } \\
& \text { Intensive Care Medicine } \\
& \text { 1999; } Y \leqslant: 1 \cdot \leqslant \cdot-1 \cdot \leqslant \text {. }
\end{aligned}
$$

I $\leqslant$ - Boswell TC, Fox PC. Reduction in MRSA environmental contamination with a portable HEPA-filtration unit. journal of hospital infection. $r_{\ldots}, \tau ; \tau r(1): \leqslant V_{-}$ $0 \leqslant$.

10. Vandepitte J, Verhaegen J, Engbaek K, et al. Basic laboratory procedures in clinical bacteriology. $r^{\text {nd }} E d$. world health organization, Geneva. Y..r; $11 \cdot$.

17. Brooks G, Butel J, Morse S. Jawetz, melnick \& adelberg's Medical microbiology. $r^{\text {nd }} E d$. McGraw-Hill. $r \ldots 1 ; 10$, r r r

IV- Walker R, Edwards C. Clinical pharmacy and therapeutics. $r^{\text {nd }} \mathrm{Ed}$. Churchill livingstone. 1999; $\$ 90$.

1^. Miller J. Hospital acquired infections, Researchers Focus on
Hospital-Acquired Infection Testing and Diagnosis. Lab Medica international. $\left.\left.\Upsilon_{\cdot}\right) \cdot ; \wedge_{-}\right) \leq$.

19. Schaberg DR, Culver DH, Gaynes RP. Major trends in the microbial etiology of nosocomial infection. A

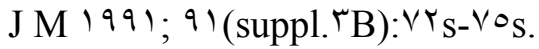

$r$-- Haslett C, Chilvers E, Boon N, et al. Davidson's Principles and Practice of Medicine. $19^{\text {th }}$ Ed. Chirchill Livingstone $r \ldots r$; or 1

r)- Koda-Kimble MA, Young LY, Kradjan WA. Applied therapeutics the clinical use of drugs. $\wedge^{\text {th }} E d$. Lippincott Williams \& Wilkins. r...०; T. - Y Y,OV_r.

Yr- Winn W Jr, Allen S, Janda W, et al. Koneman's color atlas and textbook of diagnostic microbiology. $7^{\text {th }}$ Ed. Lippincott Williams \& Wilkins Y.. ?; 1 roN_q. 